\title{
Considerations on the biochemical composition of some freshwater zooplankton species
}

\author{
Nicoletta RICCARDI* and Monica MANGONI ${ }^{1)}$ \\ CNR Istituto Italiano Idrobiologia, Largo Tonolli 50, 28922 Verbania Pallanza (VB), Italy \\ ${ }^{1)}$ J.R.C., Environment Institute, 21020 Ispra (VA), Italy \\ *e-mail corresponding author: n.riccardi@iii.to.cnr.it
}

\begin{abstract}
The mean elemental $(C, H, N)$ and biochemical composition (lipids, carbohydrates and proteins) of some abundant crustacean zooplankton species of Italian insubric lakes has been estimated by the analysis of samples collected at different seasons from various environments (Lake Maggiore, Lake Varese, Lake Comabbio, Lake Monate). From each sample an adequate number of specimens of each abundant species was sorted and analyzed by a CHN elemental analyzer. The percentage of lipids, carbohydrates and proteins and the calorific content were calculated from the elemental composition according to Gnaiger \& Bitterlich (1984). Interand intraspecific variability of biochemical composition was quite high, while elemental composition and calorific content were less variable. An estimate of the mean elemental and biochemical composition of each species was obtained by pooling the data. These mean values have been used to estimate the pools of elements and compounds in the crustacean zooplankton of Lake Comabbio to provide an example of the importance of a multiple approach in zooplankton studies.
\end{abstract}

Keywords: zooplankton, elemental composition, proximate biochemical composition, calorific content

\section{INTRODUCTION}

Zooplankton is considered an important compartment of aquatic ecosystems for its rôle in the trophic equilibrium. It represents the channel of transmission of the energy flux from the primary producers to the top consumers. Through vertical migrations, as well as sedimentation of pellets and dead individuals, it accelerates the nutrient transfer from epilimnetic to ipolimnetic waters and by grazing and nutrient release it regulates phytoplankton production and community structure. As any other organism, zooplankters influence the turnover time of those elements which are accumulated in their body during their life.

For a better understanding of zooplankton functions in the ecosystem the seasonal fluctuations of zooplankton populations can be expressed by various quantitative parameters (e.g., population density, biomass, content of elements or biochemical compounds). Each parameter emphasizes a certain characteristic of the zooplankton association, the knowledge of which is needed to evaluate the importance of one or more rôles played by zooplankton in that particular ecosystem. For instance, zooplankton biomass indicates the amount of organic matter available for eterothropic bacteria and planktivorous fish; elements content fluctuations must be considered for estimates of the importance of zooplankton pool in the element cycles.

Many studies have dealt with elemental and biochemical composition, as well as calorific content, of marine (reviewed by Båmstedt 1986; Omori \& Ikeda 1992) and freshwater zooplankton species (e.g., Birge \&
Juday 1922; Farkas 1958; Blazka 1966; Mittelholzer 1970; Baudouin \& Ravera 1972; Salonen et al. 1976; Vijverberg \& Frank 1976; Hessen 1990; Hessen \& Lyche 1991).

Most of the studies consist of laboratory research, mainly on the genus Daphnia, to evaluate the influence of species, size, developmental stage or environmental factors (e.g., temperature, quality and quantity of food) on the elemental and biochemical composition of the zooplankters (e.g., Lampert 1977; Duncan 1985; Hessen 1990; Manca et al. 1994). Less studies deal with the quantitative evaluation of the importance in the ecosystem trophy of the pool of elements and biochemical compounds composing zooplankton biomass (e.g., Zunini Sertorio et al. 1985; Behrendt 1990; Bernd Stich 1991; Hessen et al. 1992).

There are two main approaches to estimate the zooplankton pools of elements and their fluctuations: a) analysis of total or size fractionated zooplankton samples and b) the use of conversion factors. Both of these methods have obvious limitations. A high proportion of detritus frequently affects the results obtained by the first method and the relative contribution of the main taxa can only be roughly estimated by size fractionation and taxonomic analysis of each fraction. A successful application of the second method is based on the availability of reliable specie-specific biomass to element conversion factors.

This research aimed to obtain a reliable estimate of the mean element $(\mathrm{C}, \mathrm{H}, \mathrm{N})$ and biochemical composition of the most abundant crustacean zooplankton species of Northern Italy insubric lakes. Since element and 
biochemical composition can vary in relation to season and other environmental characteristics, which in turn affect the physiological conditions of organisms, an estimate of mean conversion factors was based on samples collected in different seasons from four lakes with different trophic degree (Lake Monate, Lake Comabbio, Lake Maggiore and Lake Varese). These data were successively applied to one lake (Comabbio) to provide an example of the more complete information on zooplankton rôle which can be achieved by a multiple approach to the study of its seasonal variations.

\section{METHODS}

Zooplankton samples were collected in different seasons (Tab. 1) from four North Italian lakes (Tab. 2). Sample collection was performed by vertical and horizontal hauls using a $200 \mu \mathrm{m}$ mesh net for larger animals and a $80 \mu \mathrm{m}$ mesh net for the smaller ones. After collection, the zooplankton was resuspended in lake water in large 5-1 bottles, kept in the dark and refrigerated to prevent animal death during the transport to the laboratory. Separation into size classes was obtained by filtration through 12 nets, used in sequence, with mesh sizes of $60,85,132,180,245,390,500,600,710,950$ and $1180 \mu \mathrm{m}$. The separation accomplished in this way was not only according to size but sometime also according to species and stage. If there was still a mixture of different species present, alive individuals (at least 500) were picked up by a fine tipped pipette to separate "pure" samples of the most abundant species.

Four phytoplankton samples collected during algal blooms and filtered through a $56 \mu \mathrm{m}$ mesh net to eliminate zooplankton were also analyzed. All zooplankton samples were resuspended in $250 \mathrm{ml}$ filtered lake water and then subsampled with a Hensen pipette. A fraction (one-tenth) was preserved in 5\% formalin for counting and measuring, the other part was dried $\left(105{ }^{\circ} \mathrm{C}\right.$ for 24 h), weighed and powdered.

A fraction of the dried sample was used to measure ash content after ignition at $430{ }^{\circ} \mathrm{C}$ for 24 hours. Carbon, nitrogen and hydrogen contents were analyzed in the dry material and in the ashes by a Carlo Erba CHN 1106 elemental analyzer.

Proximate biochemical composition and calorific values were estimated by stoichiometric equations (Gnaiger \& Bitterlich 1984). To reduce the probability of an overestimation of the protein fraction the organic nitrogen value was corrected for the expected nitrogen content in the chitinous cuticle which should amount to about $7 \%$ of total nitrogen according to Vollenweider (1985). Despite this correction an overestimation (or an underestimation) of the protein content could have oc-

Tab. 1. List of zooplankton and phytoplankton species analyzed from the four lakes. D.h.: Daphnia hyalina (Leydig), D.c.: D. cucullata (s. str. Sars); C.q.: Ceriodaphnia quadrangula (Müller); B.1.: Bythotrephes longimanus (Leydig); E.p.: Eudiaptomus padanus (s. lat. Kiefer); C.a.: Cyclops abyssorum (Sars); M.a.: Microcystis aeruginosa (Kützing); C.h.: Ceratium hirundinella (Schrank); S.u. + S.a: Synedra ulna $(\mathrm{KG})+$ S. acus $(\mathrm{KG})$.

\begin{tabular}{|c|c|c|c|c|c|c|c|c|c|}
\hline & D.h. & D.c. & C.q. & B.1. & E.p. & C.a. & M.a. & C.h. & S.u.+S.a. \\
\hline \multicolumn{10}{|l|}{ Lake Maggiore } \\
\hline March 1988 & & & & & $\mathrm{x}$ & & & & \\
\hline June 1988 & $\mathrm{x}$ & & & $\mathrm{x}$ & & & & & \\
\hline \multicolumn{10}{|l|}{ Lake Monate } \\
\hline March 1988 & $\mathrm{x}$ & & & & & & & & \\
\hline June 1988 & & & & & & & & $\mathrm{x}$ & \\
\hline July 1988 & $\mathrm{x}$ & & & & $\mathrm{x}$ & $\mathrm{x}$ & & & \\
\hline August 1988 & & & & & $\mathrm{x}$ & & & & \\
\hline March 1989 & $\mathrm{x}$ & & & & $\mathrm{x}$ & $\mathrm{x}$ & & & \\
\hline July 1989 & & & & & $\mathrm{x}$ & & & & \\
\hline September 1989 & $\mathrm{x}$ & & & & & $\mathrm{x}$ & & & \\
\hline \multicolumn{10}{|l|}{ Lake Comabbio } \\
\hline March 1988 & & $\mathrm{x}$ & & & & $\mathrm{x}$ & & & \\
\hline July 1988 & & $\mathrm{x}$ & & & $\mathrm{x}$ & & $\mathrm{x}$ & $\mathrm{x}$ & \\
\hline August 1988 & & $\mathrm{x}$ & & & $\mathrm{x}$ & & & $\mathrm{x}$ & \\
\hline October 1988 & & & $\mathrm{x}$ & & & & & & \\
\hline November 1988 & & & & & & $\mathrm{x}$ & & & \\
\hline March 1989 & & & & & & $\mathrm{x}$ & & & \\
\hline April 1989 & & $\mathrm{x}$ & & & $\mathrm{x}$ & $\mathrm{x}$ & & & \\
\hline August 1989 & & $\mathrm{x}$ & & & $\mathrm{x}$ & & & $\mathrm{x}$ & \\
\hline \multicolumn{10}{|l|}{ October 1989} \\
\hline November 1989 & & & & & & $\mathrm{x}$ & & & \\
\hline \multicolumn{10}{|l|}{ Lake Varese } \\
\hline March 1988 & & $\mathrm{x}$ & & & & $\mathrm{x}$ & & & $\mathrm{x}$ \\
\hline
\end{tabular}


Tab. 2. Morphometric characteristics and trophic degree of the four lakes from which zooplankton has been collected. ${ }^{(1)}$ de Bernardi 1984; ${ }^{(2)}$ Gaggino \& Cappelletti 1984.

\begin{tabular}{lcccc}
\hline & surface $\left(\mathrm{km}^{2}\right)$ & maximum depth $(\mathrm{m})$ & mean depth $(\mathrm{m})$ & trophic level \\
\hline Lake Maggiore $^{(1)}$ & 212.5 & 370 & 177 & oligo-mesotrophic \\
Lake Varese $^{(2)}$ & 14.8 & 26 & 10.7 & hypereutrophic \\
Lake Comabbio $^{(2)}$ & 3.4 & 8 & 4.8 & hypereutrophic \\
Lake Monate $^{(2)}$ & 2.5 & 34 & 18 & oligo-mesotrophic \\
\hline
\end{tabular}

curred since the non-protein nitrogen fraction is not constant but varies with the species (Vijverberg \& Frank 1976), with both the physiological state of the individuals and the environment characteristics.

The preserved samples were examined under the microscope and the number of animals that did not belong to the desired species was recorded. The results from only those samples with a species homogeneity of $80 \%$ or more were used in further calculations. Mean individual dry weights of the animals of the sample were calculated by dividing the total sample weight by the estimated number of individuals in the sample. Body length measures were carried out on 30-50 individuals of each sample by an image analyzer (Kontron Videoplan) connected to the microscope.

To obtain a representative estimate of the mean elemental and biochemical composition for each species the values of the samples collected from the four lakes in different seasons were pooled. The mean individual composition and calorific value were multiplied for the density of individuals in Lake Comabbio from April $22^{\text {nd }}$ to November $30^{\text {th }} 1987$ (Ravera, unpublished data). Small cyclopoids (Mesocyclops leuckarti and Thermocyclops crassus), which were not analyzed because it was impossible to obtain a sufficient sample, were assumed to have the same elemental and biochemical composition of Cyclops abyssorum. For the same reason, Bosmina longirostris, Diaphanosoma brachiurum and Chydorus sphaericus were considered similar to Daphnia cucullata. Mean individual dry weights of these two species of cyclopoids and three species of cladocerans were obtained from the literature (Dumont et al. 1975).

\section{RESULTS}

The percentage of ash and elemental and biochemical composition and the mean calorific values of the zooplankton and phytoplankton species analyzed from the various lakes and seasons are summarized in table 3 . The ash content of zooplankton ranged from 4.5 to $14.0 \%$ with the highest values measured in Daphnia and the lowest ones in Ceriodaphnia and Eudiaptomus. Phytoplankton showed a high ash content (15 - 47\%) with the exception of Ceratium hirundinella from Lake Monate $(6.7 \%)$. Elemental composition of zooplankton species varied into narrow ranges with a mean carbon, nitrogen and hydrogen concentration on ash-free dry weight of $52.8 \%, 10.7 \%$ and $7.8 \%$ respectively. Phyto- plankton showed lower carbon $(46.8 \%)$, nitrogen $(6.3 \%)$ and hydrogen $(6.5 \%)$ concentrations in comparison with zooplankton.

Inter and intraspecific variation of biochemical compounds concentrations was quite high: most of this variation was probably due to differences in the physiological state of animals caught in different seasons or to the trophic differences of the ecosystems from which they came. The scattered seasonal occurrence of most species did not allow analysis of seasonal variations. In spite of this, it was evident a seasonal variation in the biochemical composition of Daphnia cucullata from Lake Comabbio and Daphnia hyalina from Lake Monate; in both these species an increase of carbohydrate and a decrease of lipid concentrations from spring to summer have been observed (Fig. 1).

No clear differences between the various environments were evidenced, but an exhaustive comparison would have required a more intensive sampling to separate the relative effects of seasonality and other environmental characteristics. For instance, the higher concentration of lipids and the lower concentration of carbohydrates in Cyclops abyssorum (adults) from Lake Varese in comparison with those from Lake Monate and Lake Comabbio could be explained also as a season effect. Indeed, Cyclops abyssorum was sampled in Lake Varese in spring (March) while the mean values for the other two lakes included also summer and autumn samples. The spring samples of Lake Monate and Lake Comabbio had a lower lipid concentration and a higher carbohydrate concentration than those from Lake Varese but the data are not sufficiently abundant to drawn any conclusion.

Calorific values of zooplankton species showed a quite low interspecific variation ranging from 4.75 to $6.23 \mathrm{kcal} \mathrm{g}^{-1}$ d.w. Phytoplankton samples had lower caloric contents ( 2.76 to $4.55 \mathrm{kcal} \mathrm{g}^{-1} \mathrm{~d}$.w.).

Nor the calorific value neither element or biochemical composition seemed to be related with the length of individuals. As is generally stated, biochemical composition changes with the physiological state and the development stage of the animal. This was evident for the different developmental stages of Cyclops abyssorum. Nauplia had the highest protein concentration while ovigerous females showed the highest lipid concentration and, consequently, the highest calorific value.

The variations of population density, biomass (ashfree dry weight) and calorific content of zooplankton in 
Tab. 3. Mean ash and element concentrations (\% dry weight) lipids, carbohydrate and protein concentrations (\% ash free dry weight) and calorific values in zooplankton and phytoplankton species from lakes Comabbio (Co), Maggiore (Ma), Monate (Mo) and Varese (Va). No. = number of samples.

\begin{tabular}{|c|c|c|c|c|c|c|c|c|c|c|}
\hline & lake & No. & $\%$ ashes & $\% \mathrm{C}$ & $\% \mathrm{~N}$ & $\% \mathrm{H}$ & $\%$ lipids & $\%$ carbohydrates & $\%$ proteins & kcal g ${ }^{-1}$ d.w. \\
\hline \multirow[t]{2}{*}{ Daphnia cucullata } & Co & 12 & $14.04 \pm 6.05$ & $53.32 \pm 3.48$ & $10.09 \pm 0.85$ & $7.78 \pm 0.60$ & $19.84 \pm 11.12$ & $22.91 \pm 14.24$ & $57.04 \pm 4.73$ & $5.09 \pm 0.78$ \\
\hline & $\mathrm{Va}$ & 4 & $10.60 \pm 1.07$ & $54.53 \pm 1.34$ & $11.08 \pm 0.73$ & $7.96 \pm 0.28$ & $22.69 \pm 4.87$ & $14.55 \pm 8.23$ & $62.76 \pm 4.20$ & $5.41 \pm 0.26$ \\
\hline \multirow[t]{2}{*}{ Daphnia hyalina } & Mo & 9 & $12.01 \pm 1.42$ & $52.30 \pm 2.68$ & $10.97 \pm 0.65$ & $7.66 \pm 0.38$ & $16.46 \pm 7.52$ & $21.32 \pm 9.95$ & $62.22 \pm 3.66$ & $5.02 \pm 0.37$ \\
\hline & $\mathrm{Ma}$ & 2 & 12.53 & 50.23 & 11.02 & 7.56 & 13.07 & 22.88 & 64.04 & 4.75 \\
\hline Ceriodaphnia quadrangula & Co & 1 & 4.56 & 49.10 & 9.76 & 6.99 & 5.29 & 40.31 & 54.41 & 4.91 \\
\hline Bythotrephes longimanus & $\mathrm{Ma}$ & 1 & 5.61 & 51.17 & 11.11 & 7.58 & 14.12 & 22.04 & 63.85 & 5.24 \\
\hline \multicolumn{11}{|l|}{ Eudiaptomus padanus } \\
\hline (adults + copepodites) & Co & 7 & $5.24 \pm 2.12$ & $53.61 \pm 4.55$ & $8.87 \pm 1.67$ & $8.05 \pm 0.54$ & $26.93 \pm 11.52$ & $22.91 \pm 3.90$ & $50.15 \pm 8.55$ & $5.64 \pm 0.66$ \\
\hline (adults + copepodites) & Mo & 4 & $5.75 \pm 2.41$ & $53.12 \pm 1.40$ & $9.73 \pm 0.55$ & $7.56 \pm 0.20$ & $17.00 \pm 3.81$ & $29.04 \pm 5.82$ & $53.95 \pm 3.41$ & $5.44 \pm 0.14$ \\
\hline \multicolumn{11}{|l|}{ Cyclops abyssorum } \\
\hline nauplia & Co & 6 & $9.15 \pm 1.38$ & $52.05 \pm 2.18$ & $11.83 \pm 1.07$ & $7.65 \pm 0.28$ & $13.84 \pm 5.28$ & $13.36 \pm 10.10$ & $72.80 \pm 7.46$ & $5.22 \pm 0.25$ \\
\hline copepodites & & 2 & 7.44 & 53.95 & 10.34 & 7.80 & 19.63 & 18.21 & 62.16 & 5.49 \\
\hline adults & & 5 & $6.97 \pm 0.95$ & $53.37 \pm 1.58$ & $11.17 \pm 0.36$ & $7.51 \pm 0.29$ & $13.90 \pm 5.89$ & $19.77 \pm 4.08$ & $66.33 \pm 2.00$ & $5.39 \pm 0.24$ \\
\hline ovigerous females & & 2 & 5.29 & 57.91 & 8.95 & 8.50 & 34.57 & 11.17 & 54.26 & 6.23 \\
\hline nauplia & Va & 1 & 8.09 & 53.03 & 12.10 & 7.89 & 19.33 & 10.84 & 69.83 & 5.39 \\
\hline copepodites & & 2 & 9.79 & 51.06 & 11.89 & 7.96 & 18.91 & 9.92 & 71.17 & 5.09 \\
\hline adults & & 4 & $6.45 \pm 1.09$ & $53.98 \pm 1.60$ & $11.52 \pm 0.52$ & $8.06 \pm 0.30$ & $23.32 \pm 5.32$ & $9.88 \pm 8.39$ & $66.80 \pm 4.04$ & $5.62 \pm 0.23$ \\
\hline copepodites & Mo & 2 & 9.86 & 53.68 & 10.97 & 8.12 & 24.59 & 11.44 & 63.97 & 5.40 \\
\hline adults & & 3 & $10.43 \pm 1.90$ & $52.07 \pm 1.65$ & $10.96 \pm 0.27$ & $7.43 \pm 0.17$ & $12.89 \pm 3.26$ & $25.95 \pm 4.55$ & $61.17 \pm 1.46$ & $5.12 \pm 0.11$ \\
\hline Synedra ulna+ S. acus & $\mathrm{Va}$ & 2 & 46.97 & 50.03 & 8.39 & 5.87 & 4.73 & 46.79 & 48.50 & 2.76 \\
\hline Microcystis aeruginosa & Co & 1 & 45.07 & 41.84 & 8.07 & 6.29 & & & & 3.89 \\
\hline Ceratium hirundinella & $\mathrm{Co}$ & 3 & $15.15 \pm 7.10$ & $50.73 \pm 2.50$ & $3.54 \pm 1.89$ & $7.31 \pm 0.47$ & $16.32 \pm 10.31$ & $62.70 \pm 7.09$ & $20.98 \pm 11.25$ & $4.55 \pm 0.37$ \\
\hline
\end{tabular}

$$
\begin{array}{lll}
\text { Daphnia hyalina } & \text { Monate } \quad & \text { aspring } \\
& \square \text { summer }
\end{array}
$$

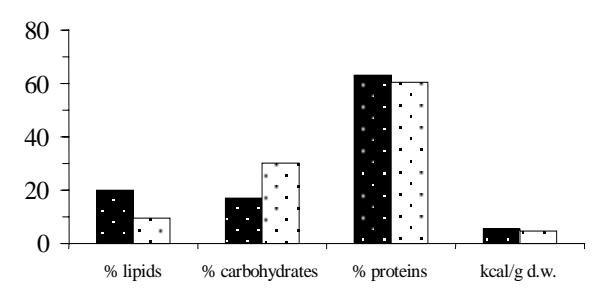

Daphnia cucullata Comabbio

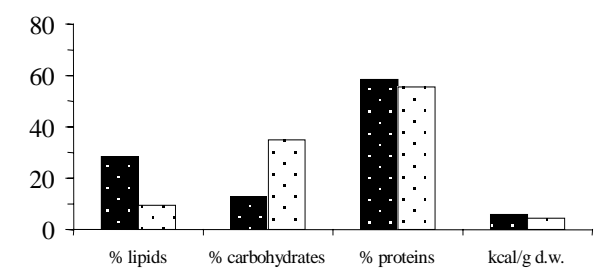

Fig. 1. Mean chemical composition and calorific values in spring and summer of Daphnia hyalina (Lake Monate) and D. cucullata (Lake Comabbio).

Lake Comabbio are schematized in figure 2. Density varied from 0.02 to 1833.8 ind $\mathrm{m}^{-3}$, with the highest value in April and the lowest in October. Biomass and calorific content showed the same seasonal trend but varied in a narrower range if compared to density values. The relative contribution of the three crustacean groups to the total zooplankton varies if the population density values are transformed into biomass (ash-free dry weight) and calorific content. The relative importance of Cladocerans obviously increases for their large body size and the low ash content of Diaptomids accounts for their relatively high contribution to the total organic matter and caloric content. The variations of lipid, carbohydrate and protein content are illustrated in figure 3. The seasonal trend and the relative contributions of the three zooplankton groups to lipid and protein variation is proportional to their relative biomass since the mean lipid and protein concentrations in the three groups are rather similar. Conversely, the seasonal trend of carbohydrates is considerably different from that of zooplankton biomass because of the very high mean carbohydrate concentration of Diaptomids, whose contribution to the total amounts to $35 \%$ over the whole period and to $80-90 \%$ in May-June when they attain their highest density.

\section{DISCUSSION AND CONCLUSIONS}

Our values for elemental and biochemical composition fall within the wide range covered by literature data (Tab. 4). Calorific values are in agreement with those reported by several authors (e.g., Birge \& Juday 1922; Slobodkin \& Richman 1961; Comita \& Schindler 1963; Prus 1970; Schindler et al. 1971; Wissing \& Hasler 1971; Salonen et al. 1976; Vijverberg \& Frank 1976).

Data on carbon and nitrogen concentrations, biochemical composition and calorific content are very abundant, while relatively few authors give data on hydrogen concentration (e.g., Vinogradov 1953; Baudouin \& Ravera 1972; Behrendt 1990; Omori \& Ikeda 1992) and ash content (e.g., Omori 1969; Prus 1970; Fujita 1971; Wissing \& Hasler 1971; Baudouin \& Ravera 1972; Salonen et al. 1976; Båmstedt 1978). 

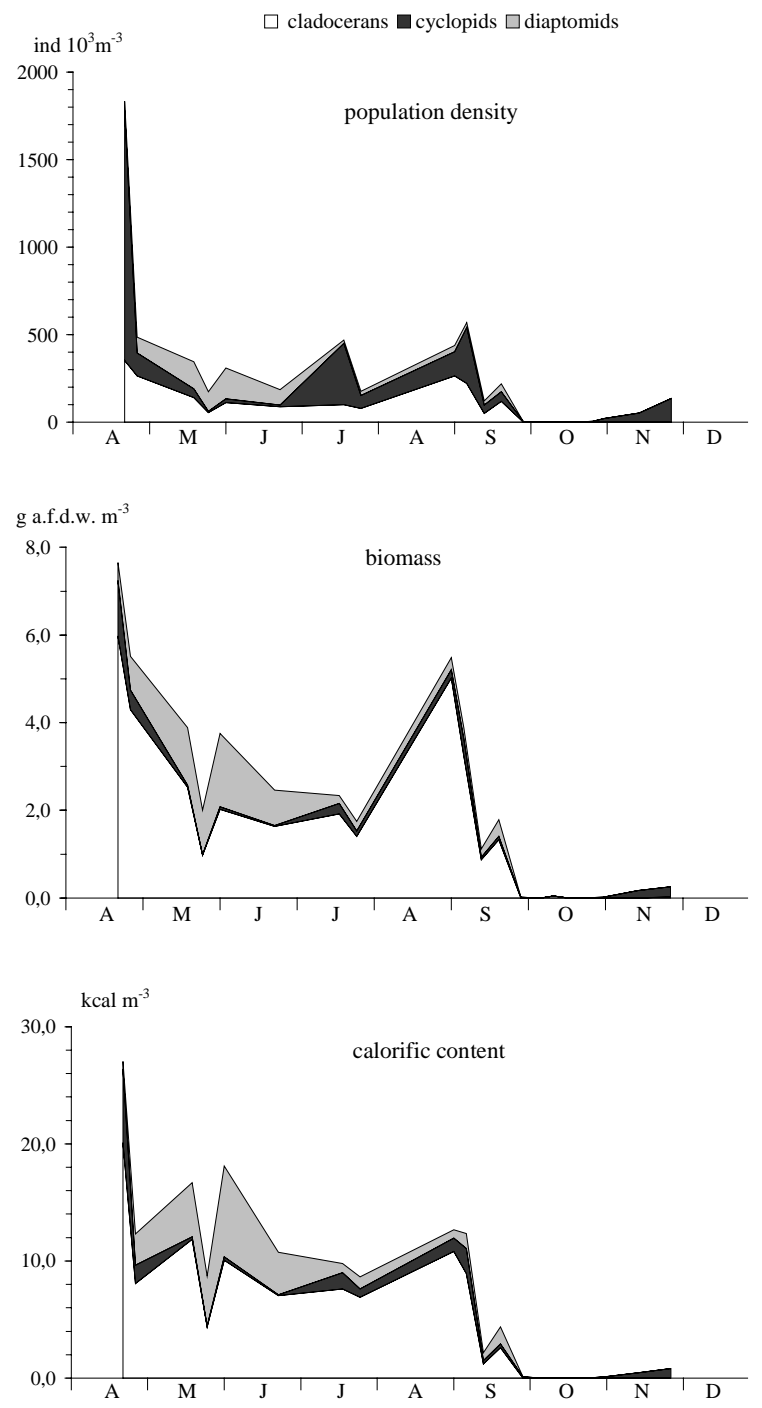

Fig. 2. Population density, biomass (ash-free dry weight) and calorific content of cladocerans, cyclopids and diaptomids in Lake Comabbio from April to November 1987.

This is not surprising because hydrogen is not important from the point of view of nutrient fluxes but only gives an indication of the reduction state of biochemical compounds allowing a stoichiometric estimation of proximate composition (e.g., Spoehr \& Milner 1949; Gnaiger \& Bitterlich 1984; Vollenweider 1985).

Conversely, most of literature values for element concentrations expressed as a percentage of the total dry weight are obviously difficult to compare if the percentage of ashes is not given, particularly in consideration of the wide inter- and intraspecific variability of ash content.

From our results, and from those reported in the literature, it is evident a strong variability of biochemical composition while elemental concentrations and calorific values are relatively more constant. The coefficient of variation calculated on literature data for freshwater
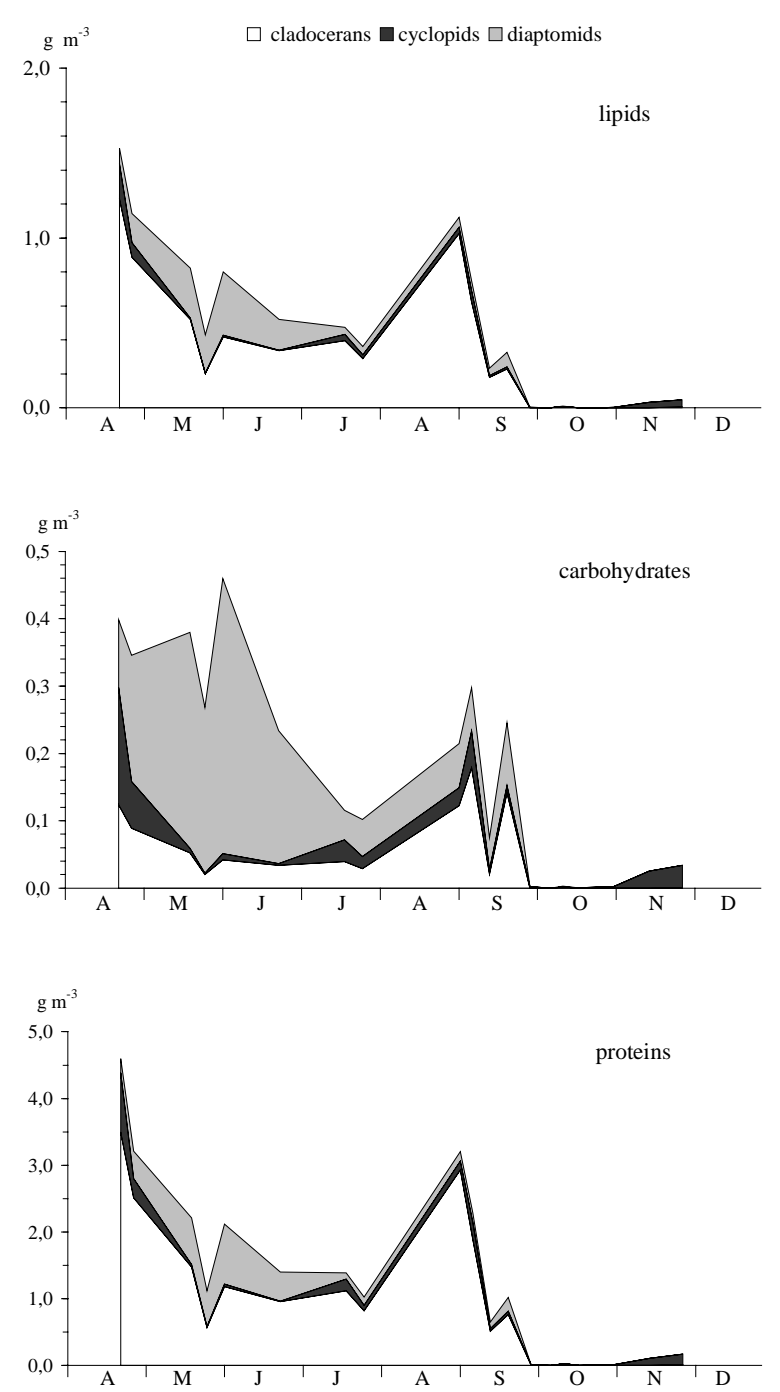

Fig. 3. Lipid, carbohydrate and protein content of cladocerans, cyclopids and diaptomids in Lake Comabbio from April to November 1987.

zooplankton varies from about $13-15 \%$ for calorific values and carbon concentrations to $27 \%$ for nitrogen concentrations, but increases to $38 \%$ for protein and 65 $70 \%$ for carbohydrate, lipids and ash contents. The same values calculated on our results range from 4-9\% for elemental and calorific content to $10 \%$ for protein and $34-43 \%$ for carbohydrate, lipids and ashes.

According to some authors (e.g., Slobodkin \& Richman 1961; Paine 1965; Prus 1970) there is some evidence of a regulation of calorific content around an optimum value, all deviations from this value undergoing selection. According to Ostapenija et al. (1968) the calorific value per gram dry organic matter falls between 4.74 and $6.42 \mathrm{kcal}$, with $5.6 \mathrm{kcal}$ being the most probable value that can be encountered among animals. A similar regulation mechanism could be expected for major elements composing living matter. De- 
Tab. 4. Range of variation of zooplankton composition from literature data (Orr 1934a, b; Vinogradov 1953; Nakai 1955; Farkas 1958; Raymont \& Conover 1961; Blazka1966; Bascheri \& Mazza 1968; Omori 1969; Mittelholzer 1970; Prus 1970; Fujita 1971; Wissing \& Hasler 1971; Guzzi 1971; Baudouin \& Ravera 1972; Nassogne 1972; Ikeda 1974; Salonen et al. 1976; Vjiverberg \& Frank 1976; Champalbert \& Kerambrun 1978; Bämstedt 1978, 1986; Grøvnik \& Hopkins 1984; Hessen 1990; Hessen \& Lyche 1991; Omori \& Ikeda 1992; Cataletto \& Fonda Umani 1994). (1) Data from Vjiverberg \& Frank (1976) have been calculated on a dry weight basis by reducing by one-fifth, as suggested by the authors, the original values (expressed as a percentage on organic matter); ${ }^{2}$ Only one value by Baudouin \& Ravera (1972) has been found.

\begin{tabular}{lcccccccc}
\hline & \multicolumn{4}{c}{$\%$ dry weight } & & \multicolumn{3}{c}{$\%$ organic matter } \\
\cline { 2 - 4 } \cline { 7 - 9 } & ashes & $\mathrm{C}$ & $\mathrm{N}$ & $\mathrm{H}$ & & carbohydrates & lipids & protein \\
\hline Freshwater cladocerans & $4.6-28.9$ & $38-55$ & $7.4-14.6^{(1)}$ & $6.3^{(2)}$ & & $6.3-53.0$ & $3.9-65.0$ & $13.0-78.1$ \\
Freshwater copepods & $2.9-5.1$ & $43-64$ & $6.2-15.1^{(1)}$ & $6.9-7.2$ & & $1.0-41.2$ & $6.0-43.2$ & $17.6-76.0$ \\
Marine copepods & $1.4-12.9$ & $39-66$ & $4.7-13.1$ & $3.2-10.3$ & & $0.2-5.1$ & $3.0-77.0$ & $30.0-82.6$ \\
\hline
\end{tabular}

spite carbon, hydrogen and nitrogen concentrations are maintained relatively constant, their allocation in the different biochemical compounds varies with the physiological state of zooplankton. Several factors, including life-stage, reproductive condition and food availability, often varying on a seasonal basis, can influence the biochemical composition of zooplankton, and particularly the concentration of reserve compounds such as lipids and carbohydrates (e.g., Conover 1968; Snow 1972; Peters 1987; Elendt 1989). Both D. hyalina and $D$. cucullata had a lower carbohydrate and a higher lipid concentration, and consequently a higher calorific value, in early spring (March) than in summer (June August). A higher fat and energy content during colder months has been reported for both copepods (e.g., Schindler et al. 1971) and cladocerans (e.g., Wissing \& Hasler 1971; Snow, 1972). Since both $D$. hyalina and $D$. cucullata had a considerably higher number of eggs/embryos in March than in summer our results are in agreement with the observation that lipid reserves and energy content increase during the reproductive period (e.g., Birge \& Juday 1922; Richman 1958). Similarly, ovigerous females of Cyclops abyssorum had more lipids and energy if compared to juveniles and adults without eggs. Neither elemental nor biochemical composition and calorific value varied with the size of animals in the present study as already reported by other authors (e.g., Comita \& Schindler 1963; Prus 1970; Baudouin \& Ravera 1972; Hessen 1990). Conversely, Richman (1958) measured an increase of calorific value with the size in cultured Daphnia pulex.

The few data on element concentrations and calorific content of some phytoplankton species fit very well with the values given by Hallergraef (1978) for mixed populations of net phytoplankton. Also the high ash content of Synedra spp. falls within the range of variation reported for diatoms by the same author, while the ash content of Microcystis aeruginosa seems to be unexplicably high. The presence of some inorganic detritus affecting the measured ash content cannot be excluded. Carbon and nitrogen concentrations (as \% on dry weight) in Synedra spp. and Microcystis aeruginosa confirm the data from Behrendt (1990). This author ob- served that carbon and nitrogen percentages on dry weight where about $24 \%$ and $4 \%$ when diatoms dominate but increased to $40 \%$ and $8 \%$ during periods of blue-greens dominance.

Fluctuations over time of density, biomass, calorific content, lipids, carbohydrate and protein contents of the three groups (Cladocerans, Diaptomids and Cyclopids) of crustacean zooplankton of Lake Comabbio have been compared. Since the period examined was only from April to November it is obviously inadequate to study the seasonal variations of zooplankton in this lake, but it is sufficient to give an example of the importance of biochemical analysis of zooplankton. From the results (Figs 2 and 3) it is evident that, as expected, the biomass (weight of organic matter) variations are similar to those of calorific content: Cladocerans dominate followed by Diaptomids while Cyclopids are less important. It is, therefore, clear that filtrators, which can potentially control phytoplankton, are dominant and that the largest Cladocerans, which are preferentially preyed on by fish, represent the greatest part of energy in this trophic level. A lower amount of energy is stored in other groups less (or not) preyed on by fish.

If density is used to describe zooplankton variations the dominance shifts towards Cyclopoids followed by Diaptomids and Cladocerans. If the same trend is expressed by protein or lipids contents the relative contribution of the three taxa is similar to that obtained by the use of biomass or energy content values. Conversely, both the seasonal trend and the proportion between taxa is completely changed if the carbohydrate content is considered because of the higher concentration measured in Diaptomids. These copepods are not generally preyed upon by fish and the substances composing their body are rapidly released in the water after their death. On the other hand, they play an important rôle in lake economy exerting a control on the edible fraction of phytoplankton and concentrating the non-edible fraction in pellets which, unlike those produced by Cladocerans, can be retained for a long time in the sediments. In conclusion, it seems therefore possible that most of lipids and protein stored into zooplankton are available to predators (fish) while most of carbohydrates are relea- 
sed in the water where presumably represent a substrate for bacteria. This hypothesis is in agreement with the observation that the metabolism of planktivorous fish is mainly based on lipid and protein utilization, carbohydrates being less (or not) assimilated.

\section{AKNOWLEDGMENTS}

We are indebted to Mr. N. Toussaint and Mr. F.G. Bo for the CHN analysis of the samples. A special thank is given to Prof. O. Ravera for the helpful suggestions during the research work and the manuscript preparation and to Dr. G. Giussani for critical discussion of the results and of manuscript draft.

\section{REFERENCES}

Båmstedt, U. 1978. Studies on the deep-water pelagic community of Korsfjorden, western Norway. Seasonal variation in weight and biochemical composition of Chiridius armatus (Copepoda) Boreomysis arctica (Mysidacea), and Eukrohnia hamata (Chaetognatha) in relation to their biology. Sarsia, 63: 145-154.

Båmstedt, U. 1986. Chemical composition and energy content. In: Corner E.D.S. \& S.C.M. O'Hara (Eds), The biological chemistry of marine copepods. Clarendon Press.

Bascheri, M.C. \& J. Mazza. 1968. Contribution à l'étude biochimique du plancton. II. Variation de teneurs en glucides et en proteins des Copépodes du golfe de Marseille. Rapp. P.-v. Réun. Commn. Int. Explor. scient. Mer Méditerr., 19: 547-549.

Baudouin, M.F. \& O. Ravera. 1972. Weight, size and chemical composition of some freshwater zooplankters: Daphnia hyalina (Leydig). Limnol. Oceanogr., 17: 645-649.

Behrendt, H. 1990. The chemical composition of phytoplankton and zooplankton in a eutrophic shallow lake. Arch. Hydrobiol., 118: 129-145.

Birge, E.A. \& C. Juday. 1922. The inland lakes of Wisconsin. The plankton. 1. Its quantity and chemical composition. Wis. Geol. Nat. Hist. Surv. Bull., 64, 222 pp.

Blazka, P. 1966. The ratio of crude protein, glycogen and fat in the individual steps of the production chain. In: Hrbacek, J. (Ed.), Hydrobiological studies. I. Academia, Publishing House of the Czechoslovak Academy of Sciences, Prague: 395-409.

Cataletto, B. \& S. Fonda Umani 1994. Seasonal variations in carbon and nitrogen content of Acartia clausi (Copepoda, Calanoida) in the Gulf of Trieste (Northern Adriatic Sea). Hydrobiologia, 292/293: 283-288.

Champalbert, G. \& P. Kerambrun. 1978. Composition biochimique des copépodes de l'hyponeuston de la Méditerranée Nord Occidentale. Pois sec et analyse élémentaire du carbon, de l'hydrogene et de l'azote. Mar. Biol., 45: 215-224.

Comita, W.G. \& D.W. Schindler. 1963. Calorific values of microcrustacea. Science, 140: 1394-1395.

Conover, R.J. 1968. Respiration and nitrogen excretion by some marine zooplankton in relation to their life cycles. $J$. mar. biol. Ass. U.K., 48: 49-75.

de Bernardi, R. 1984. Lago Maggiore. In: T. Kira (Ed.), Data book of world lakes. LBRI,NIRA Shiga Conf. 84, Otsu: 461-470.

Dumont, H.J., I. van de Velde \& S. Dumont. 1975. The dry weight estimate of biomass in a selection of Cladocera, Copepoda and Rotifera from the plankton, periphyton and benthos of continental waters. Oecologia, 19: 75-97.

Duncan, A. 1985. Body carbon in daphnids as an indicator of the food concentration available in the field. Arch. Hydrobiol. Beih., 21: 81-90.
Elendt, B.-P. 1989. Effects of starvation on growth, reproduction, survival and biochemical composition of Daphnia magna. Arch. Hydrobiol., 116: 415-433.

Farkas, T. 1958. Comparative studies on the chemical composition of lower and higher crustaceans. Annal. Biol. Tihany, 25: 179-186. (in Hungarian, German summary).

Fujita, T. 1971. Concentration of major chemical elements in marine plankton. Geochemical Journal, 4: 143-146.

Gnaiger, E. \& G. Bitterlich. 1984. Proximate biochemical composition and caloric content calculated from elemental CHN analysis: a stoichiometric concept. Oecologia, 62: 289-298.

Gaggino, G.F. \& E. Cappelletti. 1984. Catasto dei laghi italiani. Vol. I. Italia Settentrionale. Quaderni Istituto di Ricerca sulle Acque, $72: 974$ pp.

Grøvnik, S. \& C.C.E. Hopkins. 1984. Ecological investigations of the zooplankton community of Balsfjorden, Northern Norway: generation cycle, seasonal vertical distribution, and seasonal variations in body weight and carbon andi nitrogen content of the copepod Metridia longa (Lubbock). J. Exp. Mar. Biol. Ecol., 80: 93-107.

Guzzi, A. 1971. Concentrazione di calcio, potassio, fosforo, azoto, carbonio e idrogeno in diversi planctonti del Lago di Monate (Varese). Tesi di Laurea, Università degli Studi di Milano.

Hallergraef, G.M. 1978. Caloric content and elementary composition of seston of three Dutch freshwater lakes. Arch. Hydrobiol., 83: 80-98.

Hessen, D.O. 1990. Carbon, nitrogen and phosphorus status in Daphnia at varying food conditions. J. Plankton Res., 12: 1239-1249.

Hessen, D.O. \& A. Lyche. 1991. Inter- and intraspecific variations in zooplankton element composition. Arch. $\mathrm{Hy}$ drobiol., 121: 343-353.

Hessen, D.O., T. Andersen \& B. Faafeng. 1992. Zooplankton contribution to particulate phosphorus and nitrogen in lakes. J. Plankton Res., 14: 937-947.

Ikeda, T. 1974. Nutritional ecology of marine zooplankton. Mem. Fac. Fish. Hokkaido Univ., 22: 1-97.

Lampert, W. 1977. Studies on the carbon balance of Daphnia pulex De Geer as related to environmental conditions. II The dependence of carbon assimilation on animal size, temperature, food concentration and diet species. Arch. Hydrobiol., 48 (Suppl.): 310-335.

Manca, M., T. Spagnuolo \& P. Comoli. 1994. Variations in carbon and nitrogen content with body lenght of Daphnia hyalina-galeata s. 1. from laboratory and field observations. J. Plankton Res., 16: 1303-1314.

Mittelholzer, E. 1970. Populations dynamik und Production des Zooplanktons. Hydrologie, 32: 106-139.

Nakai, Z. 1955. The chemical composition, volume, weight, and size of the important marine plankton. Spec. Publ. Tpkai Fish. Res. Lab., 5: 12-24.

Nassogne, A. 1972. Etudes préliminaires sur le rôle du zooplancton dans la constitution et le transfert de la matière organique au sein de la chaîne alimentaire marine en Mer Ligure. Ph.D. Thesis Univ. Amsterdam, The Netherlands.

Omori, M. 1969. Weight and chemical composition of some important oceanic zooplankton in the North Pacific Ocean. Mar. Biol., 3: 4-10.

Omori, M. \& T. Ikeda. 1992. Methods in marine zooplankton ecology. Krieger, Malabar, Florida, U.S.A.: 330 pp.

Orr, A.P. 1934a. The weight and chemical composition of Euchaeta norvegica Boeck. Proc. Royal Soc. Edinburgh, B 54: 51-55.

Orr, A.P. 1934b. On the biology of Calanus finmarchicus. Part IV. Seasonal changes in the weight and chemical composition in Loch Fyne. J. Mar. Biol. U.K., 19: 613-632.

Ostapenija et al. 1968. Cited in: Prus, T. 1970. (in russian). 
Paine, R.T. 1965. Natural history limiting factors and energetics of the opistobranch Navanax inermis. Ecology, 46: 603-619.

Peters, R.H. 1987. Metabolism in Daphnia. Mem. Ist. ital. Idrobiol., 45: 193-243.

Prus, T. 1970. Calorific value of animals as an element of bioenergetical investigations. Pol. Arch. Hydrobiol., 17: 183199.

Raymont, J.E.G. \& R.J. Conover. 1961. Further investigations on the carbohydrate contnt of marine zooplankton. Limnol. Oceanogr., 6: 154-164.

Richman, S. 1958. The transformation of energy by Daphnia pulex. Ecol. Monogr., 28: 273-291.

Salonen, K., J. Sarvala, I. Hakala \& M.-L. Viljanen. 1976. The relation of energy and carbon in aquatic invertebrates. Limnol. Oceanogr., 21:724-730.

Schindler, D.W., A.S. Clark \& J.R. Gray. 1971. Seasonal calorific values of freshwater zooplankton, as determined with a Phillipson bomb calorimeter modified for small samples. J. Fish. Res. Bd Can., 28: 559-564.

Slobodkin, L.B. \& S. Richman. 1961. Calories/g in species of animals. Nature, London, 191: 299.

Snow, N.B. 1972. The effect of season and animal size on the caloric content of Daphnia pulicaria Forbes. Limnol. Oceanogr., 17: 909-913.

Received: November 1998

Accepted: January 1999
Spoehr, H.A. \& H.W. Milner. 1949. The chemical composition of Chlorella; effect of environmental condition. Plant Physiol., 24: 120-149.

Stich, H.B. 1991. Phosphorus and carbon values of zooplankton species in Lake Constance. Verh. int. Ver. Limnol., 24: 837-841.

Vijverberg, J. \& T.H. Frank. 1976. The chemical composition and energy contents of copepods and cladocerans in relation to their size. Freshwat. Biol., 6: 333-345.

Vinogradov, A.P. 1953. The elementary chemical composition of marine organisms. Sears Foundation for Marine research, Yale University, New Haven: 647 pp.

Vollenweider, R.A. 1985. Elemetal and biochemical composition of plankton biomass; some comments and explorations. Arch. Hydrobiol., 105: 11-29.

Wissing, T.E. \& A.D. Hasler. 1971. Intraseasonal change in caloric content of some freshwater invertebrates. Ecology, 52: 371-373.

Zunini Sertorio, T., L. Cassiani \& S. Palmero. 1985. Biochemical composition of zooplankton in coastal waters (Ligurian Sea). Mem. Biol. Mar. e Oceanogr., 15: 91-113. 